\title{
Changes in landscape ecology between nature reserve and palm oil plantation in West Java, Indonesia based on the observations of macrofungal population
}

\author{
PUTUT F. ARKO, LISDAR I. SUDIRMAN", IBNUL QAYIM \\ Department of Biology, Faculty of Mathematics and Natural Science, Institut Pertanian Bogor. Jl. Agatis, Kampus IPB Dramaga, Bogor 16680, West \\ Java, Indonesia. Tel./fax.: +62-251-8622833. `email: lisdarma @apps.ipb.ac.id, arko_pututfajar@apps.ipb.ac.id
}

Manuscript received: 23 June 2021. Revision accepted: 27 September 2021.

\begin{abstract}
Arko PF, Sudirman LI, Qayim I. 2021. Changes in landscape ecology between nature reserve and palm oil plantation in West Java, Indonesia based on the observations of macrofungal population. Biodiversitas 22: 4526-4537. As the biggest tropical country in Southeast Asia with the third-largest forest, Indonesia has limited data on macrofungal diversity. The limitation of the data is due to the lack of study on macrofungi in high biodiversity locations such as Dungus Iwul Nature Reserve (CADI). The purpose of this study was to determine and analyze the population of macrofungal species caused by the conversion in landscape structure (fragmentation and land-use change) that occurred in CADI patch and oil palm plantation of PT Perkebunan Nusantara VIII (PTPN) matrix, Cigelung, West Java. The sampling method used was opportunistic sampling assisted by line intercept. The macrofungal identification was based on morphological characters. The analysis of community ecology was performed in $\mathrm{R}$ programme. The results showed that macrofungal population and diversity in CADI were the highest, followed by PTPN planted in 2004 and planted in 2003, with a significant difference among the three study locations. The community dominance index shows the opposite, with the highest in PTPN 2003 and the lowest in CADI. These results showed changes in macrofungal population and diversity from the conversion in landscape structure. There were eleven indicator species in CADI, two species in PTPN 2003, and five species in PTPN 2004.
\end{abstract}

Keywords: Cigelung landscape, Dungus Iwul Nature Reserve, ecology, macrofungi, population

Abbreviations: CADI: Dungus Iwul Nature Reserve, macrofungi: macroscopic fungi, PTPN: oil palm plantation of PT Perkebunan Nusantara VIII

\section{INTRODUCTION}

Broad-leaved Tropical Rainforest is home to half the species of living things in the world (Olson et al. 2001). This type of forest is found in large groups in Sub-Saharan Africa, the Americas, and Southeast Asia. Indonesia has the third-largest tropical rainforest (WWF 2005). This forest ecosystem is heterogeneous and continues to be 'green' throughout the year; the canopy covering the forest floor will continue to exist. The conditions under this forest canopy have a low light intensity and high humidity (Nakamura et al. 2017). One example of an organism capable of living in these conditions is a species from the Kingdom of Fungi (Santos-Silva et al. 2011; Smith and Bonito 2012; Chen et al. 2018).

Millions of species from the tropical rainforest are still undescribed (Mora et al. 2011). From the estimated total of $1,500,000$, only $\pm 375,000$ species of fungi are known and $0.32 \%$ of them are known to be present in Indonesia (Hawksworth 2001; Mycobank 2020). These estimates show that inventory and monitoring processes need to be prioritized, especially in the locations that support fungal growth.

The data on the diversity of Indonesian macroscopic fungi (macrofungi/mushroom) are still limited due to very few studies on Indonesian fungi, especially macrofungi. On the other hand, we face a rapid decline in biodiversity both by natural processes and by human activities (Cardinale et al. 2012; Mendenhall et al. 2012; Dutta et al. 2013).

The ratio of forest destruction in Indonesia is the largest among other countries (replacing Brazil) and continues to grow at an average of 47,600 hectares per year (Margono et al. 2014; Tsujino et al. 2016; Harris et al. 2017; Turubanova et al. 2018). If this condition remains, in the next 20 years, Indonesia will become a country that has lost its largest resource, and as well millions of fungal species shall lose their habitats in Indonesian forests before their potential is explored (Kodra and Syaukani 2004).

Dungus Iwul Nature Reserve (CADI) is a lowland forest area with an altitude ranging from 600 to 800 AMSL. The status of this location was obtained, during the Dutch administration, through the Governor-general Decree of the Dutch East Indies No. 23 Staatsblad 99 dated 20 March 1931 with 9.1 ha area (BBKSDA Jabar 2016). Since then, the natural forest has changed its landscape structure and fragmented into rubber trees plantation, and eventually converted again into oil palm plantations in 2003. Studies on the diversity of macrofungi in CADI and the Oil Palm Plantation of PT Perkebunan Nusantara VIII (PTPN) Cigelung have not been carried out since the changes in landscape conditions which necessitates an urgent study in this regard. This study aims to determine 
and examine the diversity of macrofungal species caused by changes in landscape structure (fragmentation and landuse change) in CADI and PTPN, Cigelung, West Java.

\section{MATERIALS AND METHODS}

\section{Study area}

The field exploration was carried out at Dungus Iwul Nature Reserve (CADI) and PT Perkebunan Nusantara VIII (PTPN), West Java, Indonesia, planted in 2003 (PTPN 2003; block 130) and 2004 (PTPN 2004; blocks 131 and 132) Cigelung (Figure 1).

\section{Procedures}

In general, the study procedures were divided into four main stages, viz. field exploration, macrofungal fruitbodies documentation and identification, herbarium preparation, and community ecology data analysis.

\section{Field exploration}

The inventory process was carried out from October 2018 to March 2019 using opportunistic sampling methods assisted by seven transect lines that cross longitudinally. (Figure 1, dashed line) (Tadiosa and Briones 2013; Barnes et al. 2018; Gaggini et al. 2019; Piętka et al. 2019). These transect lines were evenly distributed within the study area, and stretched from the eastern side to the western side. Each study area was divided into ecotone and interior areas. Ecotone data were collected from the boundary line of each study site (Figure 1, solid line), and interior area data were collected from the seven transect lines within each study site.

\section{Macrofungal fruitbodies documentation and identification}

During the field study, the various types of macrofungal fruitbodies of agaric fungi, bird's nest fungi, bolete fungi, club and coral fungi, corticioid fungi, cup fungi, cyphelloid fungi, flask fungi, jelly fungi, polypore fungi, puffball and earthstar fungi, sterioid fungi, stinkhorn fungi, and tooth fungi were documented with cameras from different sides in their natural habitat (attached to the substrate, top, side, and bottom). Macromorphological features (form group, stature type, pileus, hymenophores, stipe, and their ornamentation), location coordinates, environmental conditions, and substrate types and conditions were measured and recorded (Andrew et al. 2013; Yilmaz and Zencirci 2016; Dawson et al. 2018).

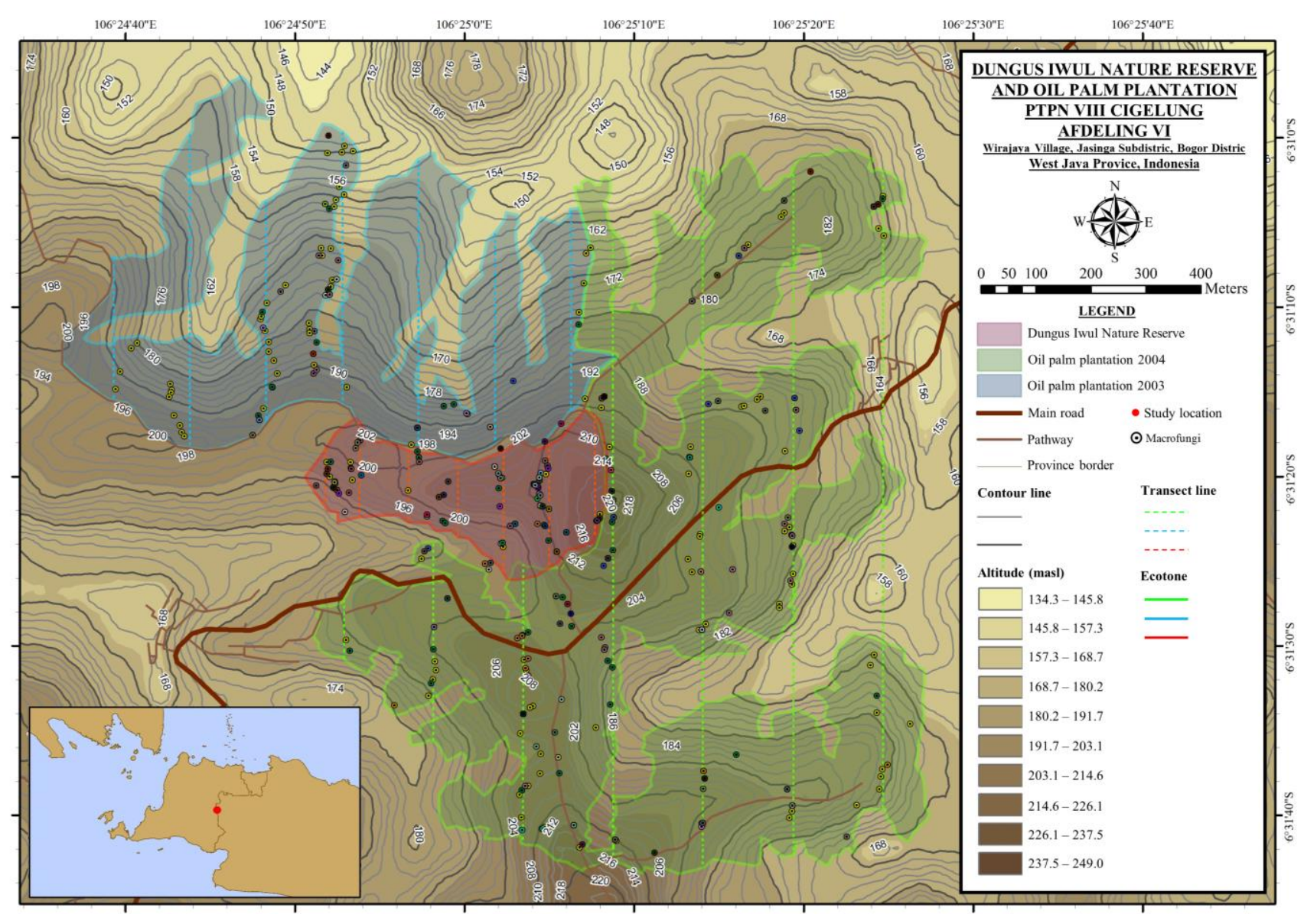

Figure 1. Location of Cigelung Landscape showing three main study locations and macrofungal distribution. 
Macrofungi that were found to have mycophagous larvae or small invertebrates on the inside and surface of its fruitbodies were noted. A total of three to five fruitbodies were gathered at different life stages. The spore prints were collected on black and white paperboard for color observation. The color description used the Munsell color system. Micromorphological features (hyphae, pellis, trama, cystidia, basidia or asci, spores, and their ornamentation) were checked and measured using a BW OPTICS XSZ-N107BN series biological microscopes with the aid of Congo red (CR) $1 \%$ and eosin (ES) $1 \%$ reagents (Dawson et al. 2018). Macrochemical tests using 5\% and $10 \%$ potassium hydroxide $(\mathrm{KOH})$ and Melzer's reagent (MR) were carried out on the surface and context of fruitbodies. Microchemical tests were carried out with MR, $\mathrm{KOH} 5 \%$, lactophenol cotton blue (CB) 1\%, and ammonium hydroxide $\left(\mathrm{NH}_{4} \mathrm{OH}\right) 10 \%$ for mycelium; and MR, CB $1 \%$ and $\mathrm{NH}_{4} \mathrm{OH} 10 \%$ for spores (Dwivedi et al. 2012; Mohanan 2014). Macrofungi were identified from the standard literature and the description of legitimate current name status registered in Mycobank database (Gäumann 1928; Thomas 1928; Corner 1950; Cooke 1961; Denison 1963; Dennis 1978; Dutta et al. 2014; Dwidjoseputro 1978; Dring 1980; Arora 1986; Gilbertson and Ryvarden 1986; Largent 1986; Singer 1986; Hjortstam et al. 1987; Miller and Miller 1988; Largent et al. 1997; Pegler et al. 1997; Spooner 2000; Lodge 2004; Deacon 2005; Halling and Mueller 2005; Cannon and Kirk 2007; Parfitt et al. 2007; Kirk et al. 2008; Læssøe 2013; Petersen 2013; Beug et al. 2014; Shay et al. 2017; Wu et al. 2017; Hussain et al. 2018; Læssøe and Petersen 2019a, b).

\section{Herbarium preparation}

Macrofungal herbaria were made by drying the macrofungal fruitbodies in an oven at a temperature of no more than $45^{\circ} \mathrm{C}$ after being wrapped in clean paper perspecimen type (Drábková 2014). The dried specimens were put in an acid-free paper envelope. The envelopes were put in ziplock plastic which had been given some silica pellets and a herbarium label (Pradhan et al. 2015).

\section{Community ecology data analyses}

Mapping and analysis of the distribution of coordinate data were carried out with ArcMap 10.3 software. Community ecology analysis was carried out with $\mathrm{R}$ programme 4.0.2 running in RStudio GUI 1.1.463. The package used in $\mathrm{R}$ was Biodiversity $R$ ver. 2.12-1, boot ver. 1.3-25, ggplot2 ver. 3.3.2, vegan ver. 2.5-6, vegan $3 d$ ver. $1.1-2$, and VennDiagram ver. 1.6.20.

\section{Data analysis}

Community data, the abundance of each species found and species richness, were standardized by the rarefaction method (based on the smallest sample size) (Johnson and Bhattacharyya 2010). The diversity indices used were Shannon-Wiener index $\left(H^{\prime}\right)$, Gini-Simpson index (1-D), the effective number of species from $\mathrm{H}^{\prime}$, community dominance index used Berger-Parker dominance, and Rényi entropy for relative measures of community diversity and evenness (Tóthmérész 1995; Jost 2006; Maurer and McGill 2010; Leinster and Cobbold 2012; Morris et al. 2014; Mbenoun et al. 2017; dos Santos et al. 2020; Nur 'Aqilah et al. 2020). Species accumulation curves were generated by collector and random methods with 1000 permutations (Schön et al. 2018; Atrena et al. 2020; Kärvemo et al. 2021). The analysis of the macrofungal species distribution was done by Venn diagram (López-Quintero et al. 2012; O'Hanlon et al. 2013; Brunner et al. 2014; Ghate et al. 2014; Wei et al. 2019; Ye et al. 2019; Runnel et al. 2021).

Analysis of macrofungal community difference was carried out using the t-test proposed by Hutcheson (1970) by comparing $\mathrm{H}^{\prime}$ and plotted with a bootstrap function using 1000 replication samples (Jost 2006). A further test of macrofungal community difference was done using the Permutational Multivariate Analysis of Variance (PERMANOVA) with Bray-Curtis dissimilarity and 999 permutations, after the equality of variation in each community group was checked with homogeneity of multivariate dispersion (Anderson and Walsh 2013). The scale of difference was described by Non-metric Multidimensional Scaling (NMDS) plot with Bray-Curtis dissimilarity and maximum iteration of 100 times (Asouti et al. 2018; Claudia et al. 2018; Abdo et al. 2019; Leonhardt et al. 2019; Lyons et al. 2021).

Analysis of indicator species was carried out with the chi-square test by observing the Pearson residual and expected value of each species (Gardener 2014). The Pearson residual of species used for this analysis were more than two in one area and no more than minus two for the other two areas. The expected value of fewer than five meant more sampling was needed for the species to be a potential indicator. The probability for finding species at each study location was calculated with the concept of rarefaction (Hurlbert 1971; Heck et al. 1975). The above analyses were done between each study location (CADI PTPN 2003 - PTPN 2004) and between the ecotone and the interior areas of each study location (CADI ecotone CADI interior; PTPN 2003 ecotone - PTPN 2003 interior; and PTPN 2004 ecotone - PTPN 2004 interior).

\section{RESULTS AND DISCUSSION}

This study recorded 6313 macrofungal samples, belonging to 120 species, 76 genera, and 41 families. All these species were scattered in CADI, PTPN 2003 and PTPN 2004 (Figure 1, colored dot). This indicates that macrofungi can live in various habitats and survive despite the changes in the landscape structure and function in oil palm plantations. The type of morphological group that was not found at the study locations was from the bolete fungi. Most morphological groups found were from agaric fungi (63 species), followed by polypore fungi ( 22 species).

Macrofungi based on the growth substrate data from all study locations showed diverse results. The difference in the growth substrate indicated different ecological functions of the macrofungi in the landscape communities 
in which they grow (Hättenschwiler et al. 2011; Rinkes et al. 2011; Rajala et al. 2012; Dickie et al. 2013; Schilling et al. 2015; Norros and Halme 2017; Runnel and Lõhmus 2017; Frąc at al. 2018; da Costa et al. 2019; Loizides et al. 2019; Lustenhouwer et al. 2020). The fruitbodies of some macrofungi can also function as a growing environment and as a food source for mycophagous larvae and small invertebrates, and other mycoparasitic fungi as well (Henk et al. 2011; Ottosson et al. 2014; Halbwachs and Bässler 2015; Baldrian et al. 2016; Schigel 2012; Epps and Arnold 2018; Kazartsev et al. 2018; Epps and Arnold 2019; Macias et al. 2019). A total of $14.17 \%$ of species from the macrofungal fruitbodies observed were a host of mycophagous larvae and small invertebrates.

In general, the growth substrates for macrofungi found were divided into soil and wood. Some macrofungal fruitbodies found growing on the soil act as mycorrhizae in association with roots, while some act as saprophytes in the final stage of wood rot, and pathogens associated with roots. The macrofungal fruitbodies found growing on the wood were found to act as saprophytes and some as a facultative parasites helping in the decay of stems, twigs, leaf sheaths, petioles, empty fruit bunches, and fruit (seeds) of plants (Ostry et al. 2011; Boddy et al. 2017).

Macrofungal fruitbodies in the CADI Fragment were found growing on wood 4.8 times more than the soil. Among these substrates, the weathered tree trunk on the forest floor was the most preferred by macrofungal fruitbodies, and the rotted tree trunk on the forest floor was preferred the least. Several species of macrofungi were associated with Orania sylvicola. These associations were possible as mycorrhizae in roots, saprophytes of plant biomass that fell to the forest floor, and facultative parasites (Tuheteru et al. 2019).

In the PTPN matrix, most of the macrofungi grew on the fallen leaf sheaths, petioles, and empty fruit bunches of Elaeis guineensis. Some macrofungal fruitbodies that grew on the soil surface were only found around the $E$. guineensis trunk, indicating a possible association with its plant roots (da Silva Maia et al. 2021). One of the substrates with high macrofungal diversity in the PTPN matrix was empty fruit bunches (tankos). This substrate was piled up around the plantation, which would rot and become an additional nutrient source for E. guineensis (Abu Bakar et al. 2011; Chiew and Shimada 2013; Santi et al. 2019). This mass of substrate and its surrounding area always had a high diversity of macrofungal fruitbodies. The growing substrate of macrofungi unique to this location compared to CADI was the fruit of E. guineensis, which was the substrate of Calocybe sp. Calocybe species are also reported to be associated with village vegetation at the significance of 0.01 in West Bengal, India (Pradhan et al. 2013). In the present study area, further study is needed to determine the specificity of Calocybe sp. for fruits of $E$. guineensis.

Macrofungal abundance varied across the study site and also the abundance was found not directly proportional to the species richness (Table 1). The range of abundance found was from 1-3694/ species. The results of the rarefaction analysis at the three study sites showed that
CADI had the highest macrofungal species richness and diversity indices compared to PTPN (Table 1 and Figure 2.A). From the effective number of species, the diversity of macrofungi in CADI appeared to be 3.36 to 6.34 times more than that of PTPN. CADI had the highest evenness of the macrofungal community than the other two locations, and all study locations showed an intermediate evenness curve pattern (Figure 2.B) (Gardener 2014). Higher evenness values indicate a more stable community and more resilient to disturbance (Deng 2012; Pickles et al. 2012; Shade et al. 2012; Griffiths and Philippot 2013; Matsushita et al. 2015; Carrillo-Saucedo et al. 2018; Yang et al. 2021). The highest dominance index value was owned by PTPN 2003, followed by PTPN 2004, and finally CADI. This high dominance index value was shown by Schizophyllum commune, which was found to be abundant compared to other species and is a macrofungal species commonly found in the oil palm plantation area (Seephueak et al. 2017; Shuhada et al. 2017). The macrofungal abundance in CADI was 1510 samples and 360 of them consisted of S. commune $(23.84 \%)$, while the proportion in PTPN 2003 and PTPN 2004 was much higher (79.71\% and $63.28 \%$ respectively). This is also a cosmopolitan species and has a wide variety of hosts (growing substrates) (Fuller et al. 2013; Vulinović et al. 2018). All the results above showed that CADI had the largest macrofungal diversity, followed by PTPN 2004 and finally in PTPN 2003.

Subsequent analyses were carried out between the interior and the ecotone areas of each study location. The rarefaction analysis of the macrofungal species richness in the interior area was higher compared to the ecotone in CADI, as well as PTPN 2004, but in PTPN 2003, the ecotone was higher than the interior area (Table 1). The high macrofungal species richness in the interior area of CADI and ecotone PTPN 2003 was due to differences in the diversity of growing substrates from each study location. CADI is a lowland tropical rainforest with heterogeneous plant species and is rarely disturbed by the outside environment. This condition results in a variety of growth substrates, which results in a higher species richness of macrofungi in the interior area than its ecotone. In contrast, oil palm plantations have homogeneous plant species and the plantation floor is always cleaned. This condition results in a smaller macrofungal species richness in the interior area than its ecotone (Ye et al. 2019). The macrofungal species richness in the PTPN 2004 interior area, which was higher compared to its ecotone, was due to the presence of four piles of tankos located at the exploration area. These piles of tankos had a high macrofungal species richness ( 7 to 14 species) in a small area $\left(2\right.$ to $\left.4 \mathrm{~m}^{2}\right)$. The rarefaction results of the macrofungal species richness above and the calculation of the diversity indices showed that the highest diversity in CADI was found in the interior area compared to its ecotone, and the highest diversity in PTPN 2003 was obtained in ecotone compared to the interior area (Table 1 and Figures 2.C and 2.E). The diversity of macrofungal species in the interior area of CADI was 2.7 times than its ecotone, and the ecotone of PTPN 2003 was 2.2 times than its interior area 
(based on the effective number of species (Table 1). Although the interior area of PTPN 2004 had higher macrofungal species richness, the calculation of the diversity indices showed lower yields than its ecotone (Table 1). This difference was because the evenness of the macrofungal community in PTPN 2004 ecotone was higher than the interior area and it caused the curves of Rényi entropy to cross at each other (Figure 2.G-H). The evenness curve pattern in all macrofungal communities was intermediate (Figures 2.D, 2.F, and 2.H) (Gardener 2014).

The species accumulation curve formed using the collector method shows the species richness profile of macrofungi during the inventory process (Figure 3.A). In CADI, the first asymptote (eighth to tenth sampling) happened when the weather on the day before was dry and hot. The next sampling was done again on the day after rainfall (eleventh sampling), and the number of species new to the study site increased. This also happened at the PTPN 2003 curve, which reached the asymptote phase in the fourth sampling and increased in the seventh sampling. It showed that weather conditions and sampling time affected the species richness of macrofungi (Gates et al. 2011; Dutta et al. 2013; Karim et al. 2013; Zotti et al. 2013; Hofmeister et al. 2014; Piepenbring et al. 2015; Marzana et al. 2018; Chakraborty 2019; Filippova and Lapshina 2019; Kouki and Salo 2020; Fink et al. 2021; Kujawska et al. 2021). The result of the species accumulation curve with the random method showed all study sites hadn't reached the asymptote (Figure 3.B). The boundary of confidence interval $(95 \%)$ distance from each curve still looked wide and didn't converge with the midline, indicating that there were species that were still not recorded during sampling.

The distribution composition analysis of macrofungal species using the Venn diagram shows the similarity of species at the three study sites (Figure 4.A). Seven species were tolerant of microclimate in Cigelung Landscape, and the other species preferred specific environmental conditions. Of the 120 species found, 52 were speciesspecific to CADI (remnant patches of lowland tropical rainforest) and may have disappeared from the PTPN matrix. The loss of macrofungal species richness from the PTPN matrix was accompanied by the discovery of 50 $(8+5+37)$ species that grew specifically only in that matrix. The remaining three species were found to be tolerant to the microclimate CADI and PTPN 2003 and eight species between the microclimates of CADI and PTPN 2004. The composition of the macrofungal species distribution between the interior area and its ecotone showed some differences in the macrofungal species richness (Figure 4.B). From these results, it can be concluded that several species of macrofungi are sensitive to environmental conditions and are suitable as indicator species for lowland tropical rainforest ecosystems that are not disturbed by human activity (O'Hanlon and Harrington 2012; Abrego et al. 2017; Dvořák et al. 2017).

Based on the Hutcheson t-test and bootstrap function of the $\mathrm{H}^{\prime}$, there was a significant difference between CADI with PTPN $2003(\mathrm{t}=11.83399 ; \mathrm{p}=0.0016)$, CADI with PTPN $2004(\mathrm{t}=7.3027 ; \mathrm{p}=0.0035)$, and PTPN 2003 with PTPN $2004(\mathrm{t}=3.49978 ; \mathrm{p}=0.01850)$ after the $\mathrm{p}$-value was adjusted by the Holm (1979) method (Figure 5.A). The PERMANOVA test results further supported the differences of the macrofungal community in the three study locations $(\mathrm{F}=0.036)$ with equal variation sample data $(\mathrm{F}=0.3286)$ in $\alpha$ value of 0.05 . The differences in these communities were illustrated by the NMDS analysis plotted in a three-dimensional area. The three separate centroids represent a different macrofungal community with a stress value of 0.1281 (Figure 5.B). The significant difference between the diversity index and the macrofungal community proved that there the alteration in landscape structure and function led to a change in macrofungal diversity.

Table 1. Abundance, species richness, diversity indices, and community dominance index of macrofungi in CADI fragments and PTPN matrix

\begin{tabular}{|c|c|c|c|c|c|c|c|}
\hline Location & $\begin{array}{c}\text { Macrofungal } \\
\text { abundance }\end{array}$ & $\begin{array}{c}\text { Macrofungal } \\
\text { species richness }\end{array}$ & $\begin{array}{c}\text { Standardized macrofungal } \\
\text { species richness a }\end{array}$ & $1-D^{b}$ & $\mathbf{H}^{\prime} \mathbf{c}$ & $\begin{array}{l}\text { Effective number } \\
\text { of species }\end{array}$ & $\begin{array}{c}\text { Community } \\
\text { dominance index }\end{array}$ \\
\hline $\mathrm{CADI}^{\mathrm{f}}$ & 1,510 & 70 & 70 & 0.90 & 2.84 & 17.18 & $0.26 \pm 0.10$ \\
\hline PTPN $2003^{f}$ & 1,794 & 23 & 22 & 0.38 & 1.00 & 2.71 & $0.78 \pm 0.28$ \\
\hline PTPN $2004^{\mathrm{f}}$ & 3,009 & 57 & 49 & 0.60 & 1.63 & 5.11 & $0.61 \pm 0.21$ \\
\hline Total & 6,313 & 120 & 115 & 0.68 & 2.18 & 8.85 & $0.55 \pm 0.28$ \\
\hline
\end{tabular}

\section{CADI}

Interior

Ecotone

$$
1,398
$$

112

61

15

1,400

394

13
14

\section{2,452}

557

Interior

Ecotone
37.99

15.00 $\begin{array}{ll}0.93 & 3.14\end{array}$

$\begin{array}{ll}0.84 & 2.15\end{array}$
23.04

8.56

$0.29 \quad 0.71$

$\begin{array}{ll}0.61 & 1.49\end{array}$

2.04

4.44

0.84

0.61

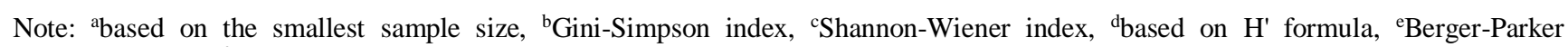
dominance index, ${ }^{\mathrm{f}}$ ecotone and interior area 

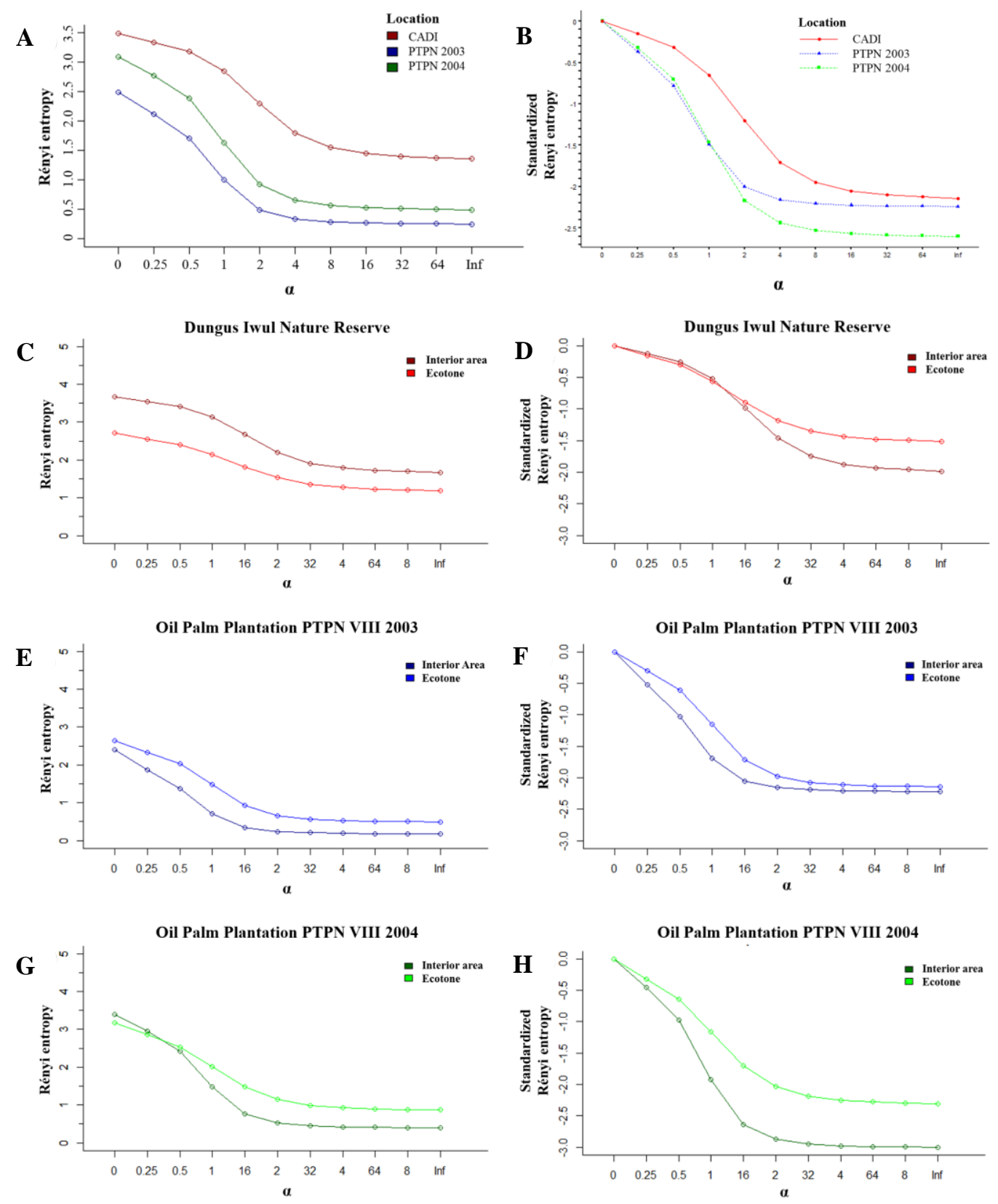

Figure 2. Rényi entropy (left) shows relative measures of community diversity and its standardization (right) shows relative measures of community evenness from each study site (A and B); CADI ecotone and interior area (C and D); PTPN 2003 ecotone and interior area (E and F); and PTPN 2004 ecotone and interior area $(\mathrm{G}$ and $\mathrm{H})$

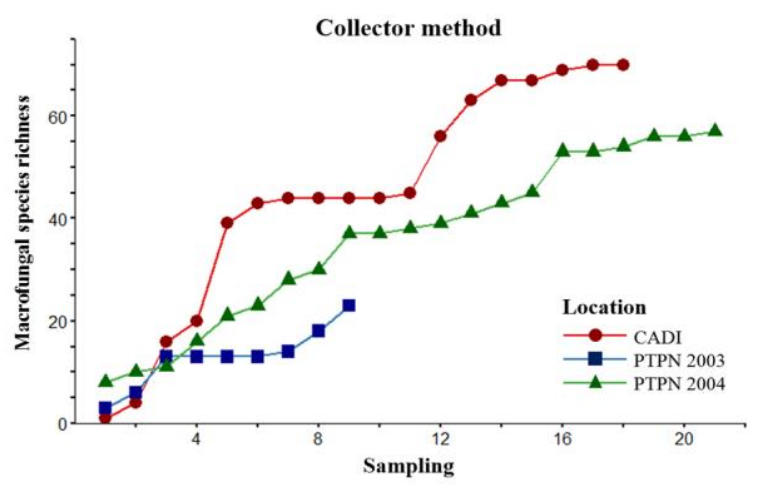

A

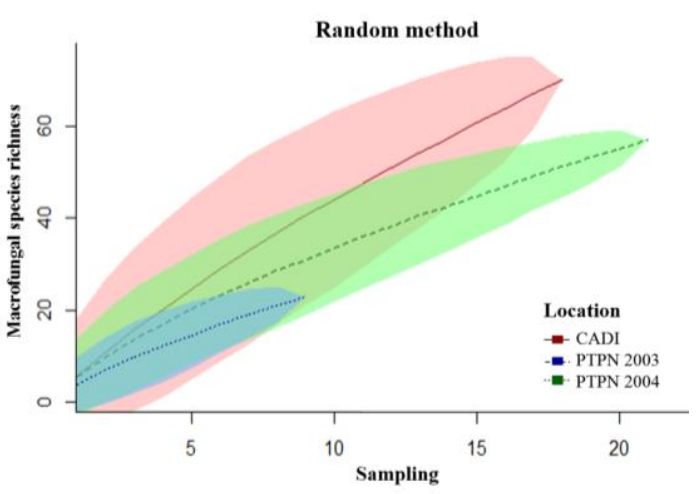

B

Figure 3. Species accumulation curves from the three study locations generated with collector (A) and random (B) methods with $95 \%$ confidence interval 


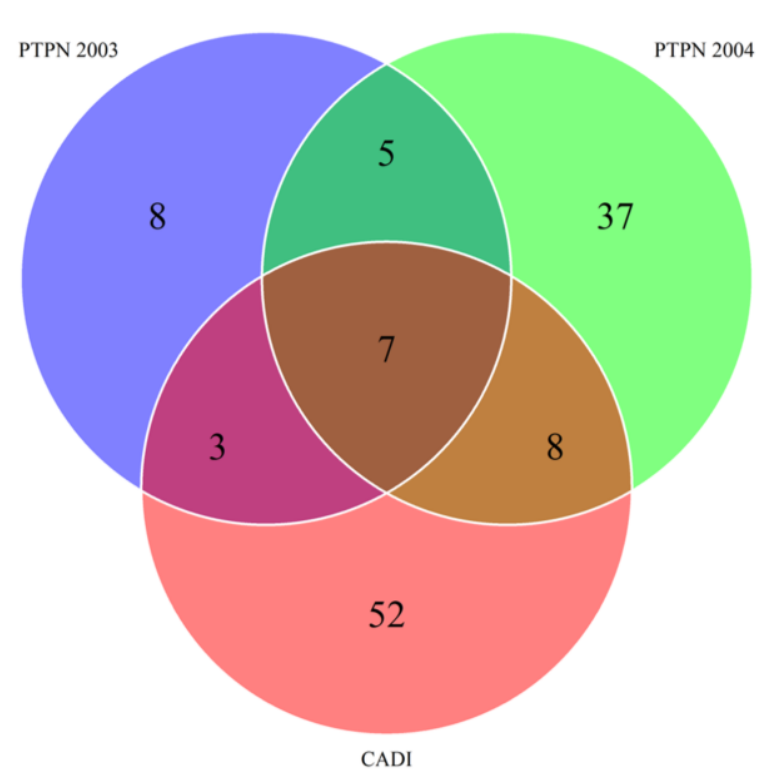

A
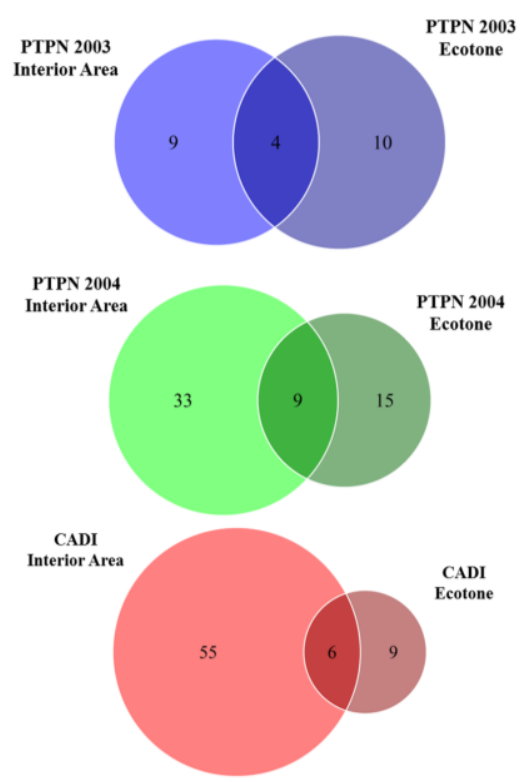

B

Figure 4. A. Venn diagram from the composition of macrofungal species richness between three study locations; and B. between interior and ecotone area in CADI (right bottom), PTPN 2003 (right top), and PTPN 2004 (right middle)

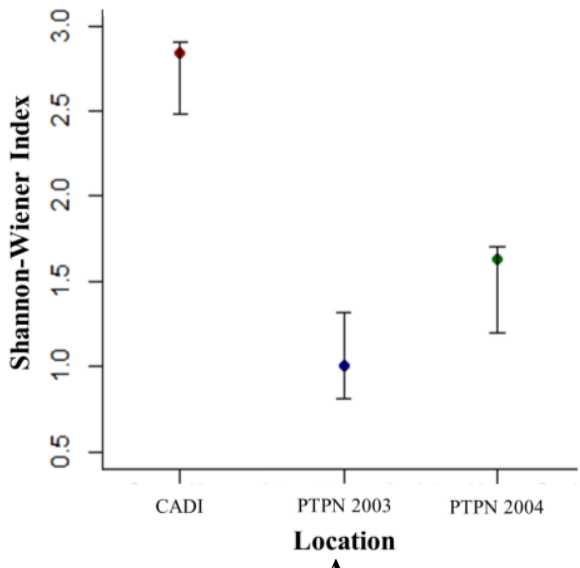

A

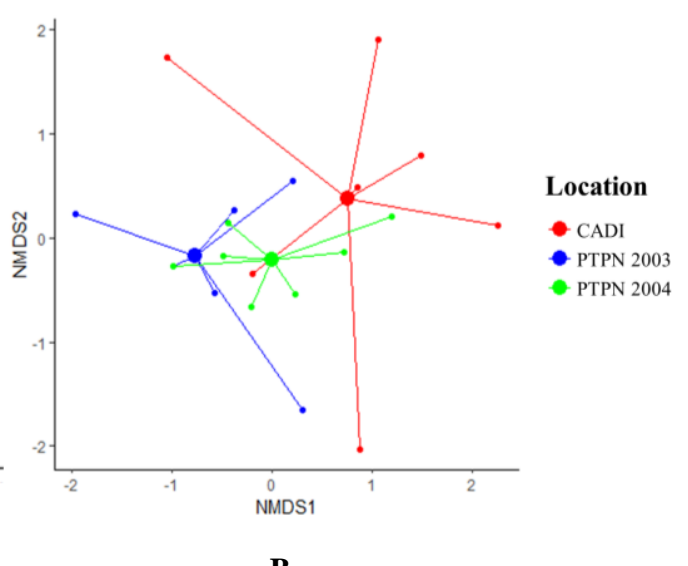

B

Figure 5. A. Bootstrap of $H^{\prime}$ with $95 \%$ confidence interval using 1000 replicated samples between three study locations. B. NMDS analysis of the macrofungal community with Bray-Curtis dissimilarity

The Hutcheson t-test and bootstrap function of the $\mathrm{H}^{\prime}$ shows that there was a significant difference between the diversity in the ecotone and interior areas of CADI $(\mathrm{t}=8.45$; $\mathrm{p}=0.01133)$, PTPN $2003(\mathrm{t}=8.33167 ; \mathrm{p}=0.002095)$, and PTPN 2004 ( $\mathrm{t}=5.9488 ; \mathrm{p}=0.002466)$ with $\alpha$ value of 0.05 (Figure 6). This significant difference between the ecotone and interior areas indicates that the macrofungal community is sensitive to the difference in the environmental conditions of the ecotone microclimate.

Macrofungal species that have potential as an indicator was analyzed with chi-square test. Species with the potential as indicator species for natural lowland tropical rainforest in Cigelung Landscape with its probability to find the species in the study location were Calocera cornea (13.32\%), Calocybe sp. (9.10\%), Cyclomyces setiporus (22.41\%), Earliella scabrosa (16.06\%), Favolus manipularis (12.50\%), Macrotyphula $\mathrm{sp}_{.1} \quad(7.22 \%)$, Marasmius sp.3 (9.10\%), Microporus affinis (27.75\%), Pholiota sp.2 (13.77\%), Rigidoporus sp., (12.36\%), and
Xylaria hypoxylon (12.04\%) (Figure 7). For Ganoderma tropicum (5.91\%), Lentinus strigosus (6.46\%), and Marasmius $\mathrm{sp} .2_{2}(11.59 \%)$, it was necessary to collect more samples to determine its potential as an indicator species candidate. Crepidotus applanatus $(9.10 \%)$ and Daldinia concentrica $(21.83 \%)$, were both candidates for indicator species but could also be found in other study locations (9.95\% in PTPN 2003 and 4.49\% in PTPN 2004), meaning that these species had a preference for CADI. The species that were uniquely found in PTPN 2003 were Hemimycena cucullata (14.28\%) and Hygrocybe cantharellus (7.87\%), while the ones in PTPN 2004 were Coprinopsis sp.1 (9.02\%), Gymnopilus dilepis (8.93\%), Lycoperdon perlatum (8.57\%), Mycena inclinata (8.57\%), and Pleurotus sp. (19.51\%). The species Lactarius $\mathrm{sp} .2_{2}$, apart from being found in PTPN 2004 (10.80\%), was also found in the CADI area $(0.91 \%)$, meaning that this species had a preference for PTPN 2004. 


\section{CADI}

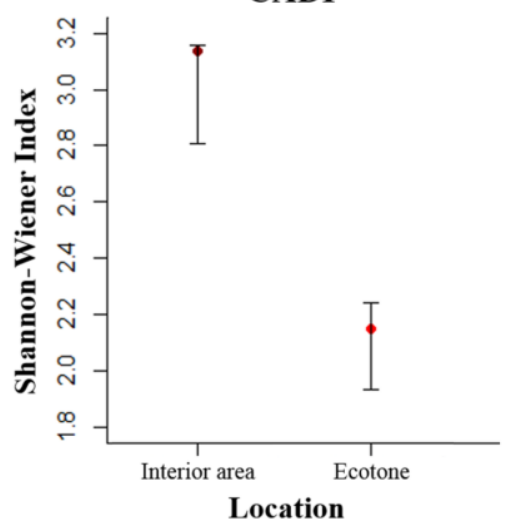

A

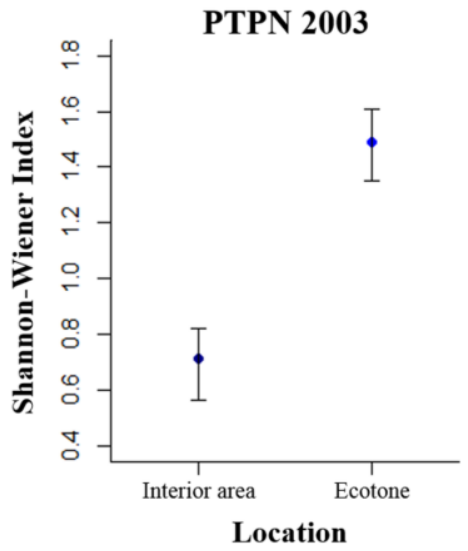

B

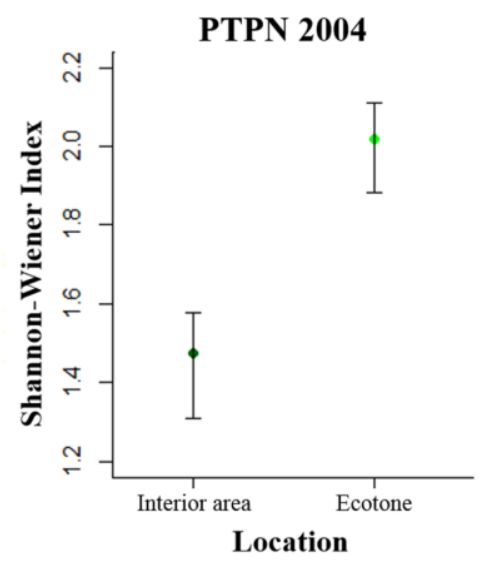

C

Figure 6. Bootstrap of $\mathrm{H}^{\prime}$ with a $95 \%$ confidence interval using 1000 replicated samples between ecotone and interior area of CADI (A), PTPN 2003 (B), and PTPN 2004 (C)

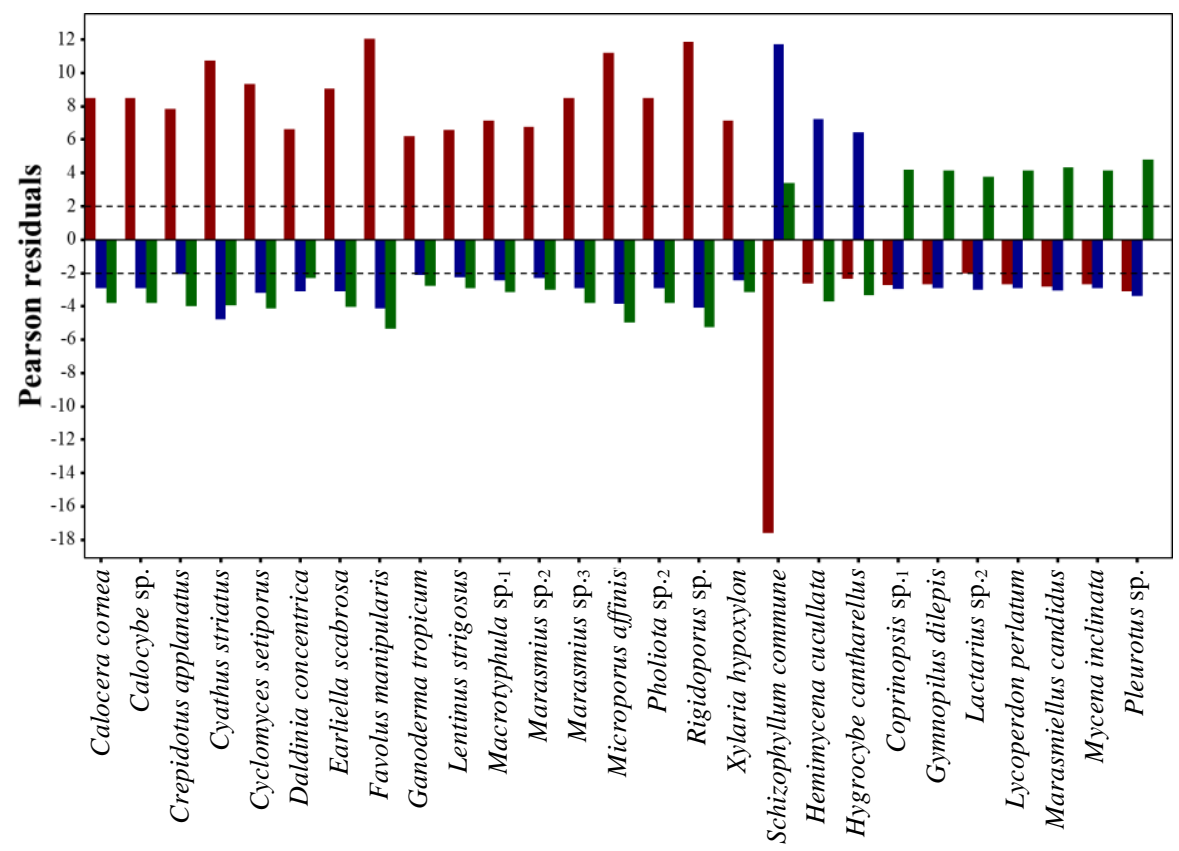

Species

\section{Location $\square$ CADI $\square$ PTPN $2003 \square$ PTPN 2004}

Figure 7. Pearson residuals from species with a score of no less than 2 in one study site and no more than -2 in the other study sites

In conclusion, the highest morphological group found belonged to agaric fungi, with $S$. commune being the most dominant in all study locations. Changes in landscape structure (fragmentation and land-use change) occurred in Cigelung Landscape, West Java, which resulted in changes in macrofungal diversity. Macrofungi had a different response and sensitivity to environmental conditions (microclimate) between the ecotone and interior area. Lastly, we suggest regularly carrying out further inventory and monitoring processes to obtain a complete diversity of macrofungal species and further exploring their potential.

\section{ACKNOWLEDGEMENTS}

This paper including the research would not have been possible without the permission from Minister of Environment and Forestry, Balai Besar Konservasi Sumber Daya Alam (BBKSDA) West Java and PT Perkebunan Nusantara VIII.

\section{REFERENCES}

Abdo Z, LeCureux J, LaVoy A, Eklund B, Ryan EP, Dean GA. 2019. Impact of oral probiotic Lactobacillus acidophilus vaccine strains on 
the immune response and gut microbiome of mice. PLoS One 14 (12): e0225842. DOI: 10.1371/journal.pone.0225842

Abrego N, Christensen M, Bässler C, Ainsworth AM, Heilmann-Clausen J. 2017. Understanding the distribution of wood-inhabiting fungi in European beech reserves from species-specific habitat models. Fungal Ecol 27: 168-174. DOI: 10.1016/j.funeco.2016.07.006

Abu Bakar R, Darus SZ, Kulaseharan S, Jamaluddin N. 2011. Effects of ten year application of empty fruit bunches in an oil palm plantation on soil chemical properties. Nutr Cycl Agroecosyst 89: 341-349. DOI: $10.1007 / \mathrm{s} 10705-010-9398-9$

Anderson MJ, Walsh DCI. 2013. PERMANOVA, ANOSIM, and Mantel test in the face of heterogeneous dispersion: What null hypothesis are you testing. Ecol Monogr 83: 557-574. DOI: 10.1890/12-2010.1

Andrew EE, Kinge TR, Tabi EM, Thiobal N, Mih AM. 2013. Diversity and distribution of macrofungi (mushrooms) in the Mount Cameroon Region. J Ecol Nat Environ 5: 318-334. DOI: 10.5897/JENE2013.0379

Arora D. 1986. Mushrooms Demystified. Ten Speed Press, California.

Asouti E, Ntinou M, Kabukcu C. 2018. The impact of environmental change on Palaeolithic and Mesolithic plant use and the transition to agriculture at Franchthi Cave, Greece. PLoS One 13 (11): e0207805. DOI: 10.1371/journal.pone.0207805

Atrena A, Banelytė GG, Læssøe T, Riis-Hansena R, Bruun HH, Rahbek C, Heilmann-Clausen J. 2020. Quality of substrate and forest structure determine macrofungal richness along a gradient of management intensity in beech forests. Forest Ecol Manag 478: 118512. DOI: 10.1016/j.foreco.2020.118512

Baldrian P, Zrůstová P, Tláskal V, Davidová A, Merhautová V, Vrška T. 2016. Fungi associated with decomposing deadwood in a natural beech-dominated forest. Fungal Ecol 23: 109-122. DOI 10.1016/j.funeco.2016.07.001

Barnes CJ, van der Gast CJ, McNamara NP, Rowe R, Bending GD. 2018 Extreme rainfall affects assembly of the root-associated fungal community. New Phytol 220: 1172-1184. DOI: 10.1111/nph.14990

BBKSDA Jabar. 2016. CA Dungus Iwul. Balai Besar KSDA Jabar. http://bbksda-jabar.dephut.go.id/?q=kawasan/dungusiwul [Indonesian]

Beug MW, Bessette AE, Bessette AR. 2014. Ascomycete Fungi of North America: A Mushroom Reference Guide. University of Texas Press, Texas.

Boddy L, Hiscox J, Gilmartin EC, Johnston SR, Heilmann-Clausen J. 2017. Wood Decay Communities in Angiosperm Wood. In: Dighton J, White JF (eds) The Fungal Community Its Organization and Role in the Ecosystem, Fourth Edition. CRC Press, Florida.

Brunner I. Frey B, Hartmann M, Zimmermann S, Graf F, Suz LM, Niskanen T, Bidartondo MI, Senn-Irlet B. 2017. Ecology of alpine macrofungi - combining historical with recent data. Front Microbiol 8: 2066. DOI: 10.3389/fmicb.2017.02066

Cannon PF, Kirk PM. 2007. Fungal Families of the World. CABI, Wallingford.

Cardinale B, Duffy J, Gonzalez A, Hooper DU, Perrings C, Venail P, Narwani A, Mace GM, Tilman D, Wardle DA, Kinzig AP, Daily GC, Loreau M, Grace JB, Larigauderie A, Srivastava DS, Naeem S. 2012 Biodiversity loss and its impact on humanity. Nature 486: 59-67. DOI: 10.1038 /nature11148

Carrillo-Saucedo SM, Gavito ME, Siddique I. 2018. Arbuscular mycorrhizal fungal spore communities of a tropical dry forest ecosystem show resilience to land-use change. Fungal Ecol 32: 29-39. DOI: 10.1016/j.funeco.2017.11.006

Chakraborty TK. 2019. Macrofungi of Dakshin Dinajpur District of West Bengal, India. NeBIO 10:66-76

Chen Y, Svenning JC, Wang X, Cao R, Yuan Z, Ye Y. 2018. Drivers of macrofungi community structure differ between soil and rotten-wood substrates in a temperate mountain forest in China. Front Microbiol 9: 37. DOI: $10.3389 /$ fmicb. 2018.00037

Chiew YL, Shimada S. 2013. Current state and environmental impact assessment for utilizing oil palm empty fruit bunches for fuel, fiber and fertilizer - A case study of Malaysia. Biomass Bioenergy 51: 109124. DOI: 10.1016/j.biombioe.2013.01.012

Claudia MOL, Francioli D, Gómez-Brandón M, Ascher-Jenull J, Bardelli T, Pietramellara G, Egli M, Sartori G, Insam H. 2018. Culturable fungi associated with wood decay of Picea abies in subalpine forest soils: a field-mesocosm case study. iForest 11: 781-785. DOI: 10.3832/ifor2846-011

Cooke WB. 1961. The Cyphellaceous fungi: A study in the Porotheleaceae. Beih Sydowia 4: 1-144
Corner EJH. 1950. A Monograph of Clavaria and Allied Genera. Oxford University Press, London.

da Costa RR, Vreeburg SME, Shik JZ, Aanen DK, Poulsen M. 2019. Can interaction specificity in the fungus-farming termite symbiosis be explained by nutritional requirements of the fungal crop? Fungal Ecol 38: 54-61. DOI: 10.1016/j.funeco.2018.08.009

da Silva Maia R, Vasconcelos SS, Viana-Junior AB, Castellani DC, Kato OR. 2021. Oil palm (Elaeis guineensis) shows higher mycorrhizal colonization when planted in agroforestry than in monoculture. Agrofor Syst 95: 731-740. DOI: 10.1007/s10457-021-00627-5

Dawson SK, Boddy L, Halbwachs H, Bässler C, Andrew C, Crowther TW, Heilmann-Clausen J, Nordén J, Ovaskainen O, Jönsson M. 2018. Handbook for the measurement of macrofungal functional traits: A start with basidiomycete wood fungi. Funct Ecol 33: 372-387. DOI: $10.1111 / 1365-2435.13239$

Deacon JW. 2005. Fungal Biology, 4th edition. Blackwell Scientific, Oxford. DOI: 10.1002/9781118685068

Deng H. 2012. A review of diversity-stability relationship of soil microbial community: What do we not know?. J Environ Sci 24: 1027-1035. DOI: 10.1016/S1001-0742(11)60846-2

Denison WC. 1963. A preliminary study of the operculate cup-fungi of Costa Rica. Rev Biol Trop 11: 99-129

Dennis RWG. 1978. British Ascomycetes. J. Cramer, Vaduz.

Dickie IA, Martínez-García LB, Koele N, Grelet GA, Tylianakis JM, Peltzer DA, Richardson SJ. 2013. Mycorrhizas and mycorrhizal fungal communities throughout ecosystem development. Plant Soil 367: 11-39. DOI: 10.1007/s11104-013-1609-0

dos Santos GR, Magallanes SRS, Haesbaert FM, Rotili EA, Cachoeira JN, Alves MVG. 2020. Fire effects on soil fungi in a Cerrado Vegetation Area according to the collection period. Floresta 50: 1113-1122. DOI: 10.5380/rf.v50i1.61754

Drábková LZ. 2014. DNA Extraction from Herbarium Specimens. In: Besse P (ed) Molecular Plant Taxonomy: Methods and Protocols, Methods in Molecular Biology. Humana Press, Totowa, NJ. DOI: 10.1007/978-1-62703-767-9_4

Dring DM. 1980. Clathraceae. Kew Bull 35: 1-96. DOI: 10.2307/4117008

Dutta AK, Pradhan P, Basu SK, Acharya K. 2013. Macrofungal diversity and ecology of the mangrove ecosystem in the Indian part of Sundarbans. Biodiversity 14: 196-206. DOI: 10.1080/14888386.2013.848824

Dutta AK, Chandra S, Pradhan P, Acharya K. 2014. A new species of Marasmius Sect. Sicci from India. Mycotaxon 128: 117-125. DOI: 10.5248/128.117

Dvořák D, Vašutová M, Hofmeister J, Beran M, Hošek J, Bět'ák J, Burel J, Deckerová H. 2017. Macrofungal diversity patterns in central European forests affirm the key importance of old-growth forests. Fungal Ecol 27: 145-154. DOI: 10.1016/j.funeco.2016.12.003

Dwidjoseputro D. 1978. Pengantar Mikologi. Alumni, Bandung. [Indonesian]

Dwivedi S, Tiwari MK, Chauhan UK, Pandey AK. 2012. Biodiversity of mushrooms of Amarkantak biosphere reserve forest of Central India. Int J Pharm Biol Sci 3: 1363-1367

Epps MJ, Arnold AE. 2018. Quantifying beetle-macrofungal associations in a temperate biodiversity hot spot. Mycologia 110: 269-285. DOI: 10.1080/00275514.2018.1430439

Epps MJ, Arnold AE. 2019. Interaction networks of macrofungi and mycophagous beetles reflect diurnal variation and the size and spatial arrangement of resources. Fungal Ecol 37: 48-56. DOI: 10.1016/j.funeco.2018.11.001

Filippova N, Lapshina E. 2019. Sampling event dataset on five-year observations of macrofungi fruit bodies in raised bogs, Western Siberia, Russia. Biodivers Data J 7: e35674. DOI: 10.3897/BDJ.7.e35674

Fink S, Gross A, Senn-Irlet B, Scheidegger C. 2021. Citizen science data predict high potential for macrofungal refugia outside protected riparian areas. Fungal Ecol 49: 100981. DOI: 10.1016/j.funeco.2020.100981

Frąc M, Hannula SE, Bełka M, Jędryczka M. 2018. Fungal biodiversity and their role in soil health. Front Microbiol 9: 707. DOI: 10.3389/fmicb.2018.00707

Fuller RJM, Johnston PR, Pearson MN. 2013. Schizophyllum commune:a case study for testing the potential introduction of non-native strains into New Zealand. $\mathrm{N} \quad \mathrm{Z}$ J Bot 51: 286-296. DOI: $10.1080 / 0028825 X .2013 .829503$

Gaggini L, Rusterholz H, Baur B. 2019. The annual invasive plant Impatiens glandulifera reduces hyphal biomass of soil fungi in 
deciduous forests. Fungal Ecol 39: 242-249. DOI: 10.1016/j.funeco.2018.12.004

Gardener M. 2014. Community Ecology: Analytical Methods Using R and Excel. Pelagic Publishing, Devon.

Gates GM, Mohammed C, Wardlaw T, Davidson NJ, Ratkowsky DA 2011. Diversity and phenology of the macrofungal assemblages supported by litter in a tall, wet Eucalyptus obliqua forest in southern Tasmania, Australia. Fungal Ecol 4: 68-75. DOI: 10.1016/j.funeco.2010.08.001

Gäumann EA. 1928. Comparative Morphology of the Fungi. McGrawHill, New York.

Ghate SD, Sridhar KR, Karun NC. 2014. Macrofungi on the coastal sand dunes of south-western India. Mycosphere 5: 144-151. DOI: 10.5943/mycosphere/5/1/6

Gilbertson RL, Ryvarden L. 1986. North American Polypores 1, Abortiporus to Lindtneria. Fungiflora, Oslo.

Griffiths BS, Philippot L. 2013. Insights into the resistance and resilience of the soil microbial community. FEMS Microbiol Rev 37: 112-129. DOI: $10.1111 / \mathrm{j} .1574-6976.2012 .00343 . x$

Halbwachs H, Bässler C. 2015. Gone with the wind - a review on basidiospores of lamellate agarics. Mycosphere 6: 78-112. DOI 10.5943/mycosphere/6/1/10

Halling RE, Mueller GM. 2005. Common Mushrooms of the Talamanca Mountains, Costa Rica. New York. New York Botanical Garden Press, New York.

Harris NL, Goldman E, Gabris C, Nordling J, Minnemeyer S, Ansari S, Lippmann M, Bennett L, Raad M, Hansen M, Potapov P. 2017. Using spatial statistics to identify emerging hot spots of forest loss. Environ Res Lett 12: 024012. DOI: 10.1088/1748-9326/aa5a2f

Hättenschwiler S, Fromin N, Barantal S. 2011. Functional diversity of terrestrial microbial decomposers and their substrates. C R Biol 334 393-402. DOI: 10.1016/j.crvi.2011.03.001

Hawksworth DL. 2001. The magnitude of fungal diversity: the 1-5 million species estimate revisited. Mycol Res 105: 1422-1432. DOI: $10.1017 /$ S0953756201004725

Heck KL, van Belle G, Simberloff D. 1975. Explicit calculation of the rarefaction diversity measurement and the determination of sufficien sample size. Ecology 56: 1459-1461. DOI: 10.2307/1934716

Henk DA, Farr DF, Aime MC. 2011. Mycodiplosis (Diptera) infestation of rust fungi is frequent, wide spread and possibly host specific. Fungal Ecol 4: 284-289. DOI: 10.1016/j.funeco.2011.03.006

Hjortstam K, Larsson KH, Ryvarden L. 1987. The Corticiaceae of North Europe, volume 1. Fungiflora, Oslo.

Hofmeister J, Hošek J, Brabec M, Dvořák D, Beran M, Deckerová $\mathrm{H}$, Burel J, Křřž M, Borovička J, Běták J, Vašutová M. 2014. Richness of ancient forest plant species indicates suitable habitats for macrofungi. Biodivers Conserv 23: 2015-2031. DOI: 10.1007/s10531-014-0701-y

Holm S. 1979. A simple sequentially rejective multiple test procedure. Scand J Stat 6: 65-70. DOI: 10.2307/4615733

Hurlbert SH. 1971. The nonconcept of species diversity:a critique and alternative parameters. Ecology 52: 577-586. DOI: 10.2307/1934145

Hussain S, Usman M, Afshan NS, Ahmad H, Khan J, Khalid AN. 2018. The genus Coprinellus (Basidiomycota; Agaricales) in Pakistan with the description of four new species. MycoKeys 39: 41-61. DOI $10.3897 /$ mycokeys. 39.26743

Hutcheson K. 1970. A test for comparing diversities based on the Shannon formula. J Theor Biol 29: 151-154. DOI: 10.1016/00225193(70)90124-4

Johnson RA, Bhattacharyya GJ. 2010. Statistics: Principles \& Methods. Wiley, New Jersey.

Jost L. 2006. Entropy and diversity. Oikos 113: 363-375. DOI 10.1111/j.2006.0030-1299.14714.x

Karim M, Kavosi MR, Hajizadeh, G. 2013. Macrofungal communities in Hyrcanian Forests, North of Iran: Relationships with Season and Forest Types. Ecol Balk 5: 87-96

Kärvemo S, Jönsson M, Hekkala A, Sjögren J, Strengbom J. 2021. Multitaxon conservation in northern forest hot-spots:the role of forest characteristics and spatial scales. Landsc Ecol 36: 989-1002. DOI: 10.1007/s10980-021-01205-x

Kazartsev I, Shorohova E, Kapitsa E, Kushnevskaya H. 2018. Decaying Picea abies log bark hosts diverse fungal communities. Fungal Ecol 33: 1-12. DOI: 10.1016/j.funeco.2017.12.005

Kirk, PM, Cannon PF, Stalpers JA. 2008. Dictionary of the Fungi, 10th edition. CABI, Wallingford. DOI: 10.1079/9780851998268.0000
Kodra HSA, Syaukani HR. 2004. Bumi makin panas, banjir makin luas: menyibak tragedi kehancuran hutan. Nuansa, Bandung. [Indonesian]

Kouki J, Salo K. 2020. Forest disturbances affect functional groups of macrofungi in young successional forests - harvests and fire lead to different fungal assemblages. Forest Ecol Manag 463: 118039. DOI: 10.1016/j.foreco.2020.118039

Kujawska MB, Rudawska M, Stasińska M, Pietras M, Leski T. 2021. Distribution and ecological traits of a rare and threatened fungus Hericium flagellum in Poland with the prediction of its potential occurrence in Europe. Fungal Ecol 50: 101035. DOI: 10.1016/j.funeco.2020.101035

Læssøe T, Petersen JH. 2019a. Fungi of Temperate Europe. volume 1. Princeton University Press, New Jersey.

Læssøe T, Petersen JH. 2019b. Fungi of Temperate Europe. volume 2. Princeton University Press, New Jersey.

Læssøe T. 2013. Mushroom: How to Identify and Gather Wild Mushroom and Other Fungi. DK Publishing, New York.

Largent DL, Johnson D, Watling R. 1997. How to Identify Mushroom to Genus II: Microscopic Features. Mad River Press, California.

Largent DL. 1986. How to Identify Mushroom to Genus I: Macroscopic Features. Mad River Press, California.

Leinster T, Cobbold CA. 2012. Measuring diversity: the importance of species similarity. Ecology 93: 477-489. DOI: 10.1890/10-2402.1

Leonhardt S, Hoppe B, Stengel E, Noll L, Moll J, Bässler C, Dahl A, Buscot F, Hofrichter M, Kellner H. 2019. Molecular fungal community and its decomposition activity in sapwood and heartwood of 13 temperate European tree species. PLoS One 14: e0212120. DOI: 10.1371/journal.pone.0212120

Lodge DJ, Ammirati JF, O'Dell TE, Mueller GM, Huhndorf SM, Wang CJ, Stokland JN, Schmit JP, Ryvarden L, Leacock PR, Mata M, Umaña L, Wu QF, Czederpiltz DL. 2004. Collecting and describing macrofungi. In: Mueller GM, Bills GF, Foster MS (eds). Biodiversity of Fungi: Inventory and Monitoring Methods. Academic Press, Massachusetts. DOI: 10.1016/B978-012509551-8/50011-8

Loizides M, Bellanger J, Assyov B, Moreau P, Richard F. 2019. Present status and future of boletoid fungi (Boletaceae) on the island of Cyprus: Cryptic and threatened diversity unravelled by ten-year study. Fungal Ecol 41: 65-81. DOI: 10.1016/j.funeco.2019.03.008

López-Quintero CA, Straatsma G, Franco-Molano AE, Boekhout T. 2012. Macrofungal diversity in Colombian Amazon forests varies with regions and regimes of disturbance. Biodivers Conserv 21: 22212243. DOI: $10.1007 / \mathrm{s} 10531-012-0280-8$

Lustenhouwer N, Maynard DS, Bradford MA, Lindner DL, Oberle B, Zanne AE, Crowther TW. 2020. A trait-based understanding of wood decomposition by fungi. Proc Natl Acad Sci 117: 11551-11558. DOI: 10.1073/pnas.1909166117

Lyons KG, Mann M, Lenihan M, Roybal O, Carroll K, Reynoso K, Kivlin SN, Taylor DL, Rudgers JA. 2021. Culturable root endophyte communities are shaped by both warming and plant host identity in the Rocky Mountains, USA. Fungal Ecol 49: 101002. DOI: 10.1016/j.funeco.2020.101002

Macias AM, Marek PE, Morrissey EM, Brewer MS, Short DPG, Stauder CM, Wickert KL, Berger MC, Metheny AM, Stajich JE, Boyce G, Rio RVM, Panaccione DG, Wong V, Jones TH, Kasson MT. 2019. Diversity and function of fungi associated with the fungivorous millipede, Brachycybe lecontii. Fungal Ecol 41: 187-197. DOI: 10.1016/j.funeco.2019.06.006

Margono BA, Potapov PV, Turubanova S, Stolle F, Hansen MC. 2014. Primary forest cover loss in Indonesia over 2000-2012. Nat Clim Chang 4: 730-735. DOI: 10.1038/nclimate2277

Marzana A, Aminuzzaman FM, Chowdhury MSM, Mohsin SM, Das K. 2018. Diversity and ecology of macrofungi in Rangamati of Chittagong Hill tracts under tropical evergreen and semi-evergreen forest of Bangladesh. Adv Res 13: 1-17. DOI: 10.9734/AIR/2018/36800

Matsushita Y, Bao Z, Kurose D, Okada H, Takemoto S, Sawada A, Nagase H, Takano M, Murakami H, Koitabashi M, Yoshida S, Saito M, Sano T, Tsushima S. 2015. Community structure, diversity, and species dominance of bacteria, fungi, and nematodes from naturally and conventionally farmed soil:a case study on Japanese apple orchards. Org Agr 5: 11-28. DOI: 10.1007/s13165-015-0096-4

Maurer BA, McGill BJ. 2010. Measurement of species diversity. In: Magurran AE, McGill BJ (eds) Biological Diversity. Oxford University Press, Oxford.

Mbenoun M, Garnas JR, Wingfield MJ, Boyogueno ADB, Roux J. 2017. Metacommunity analyses of Ceratocystidaceae fungi across 
heterogeneous African savanna landscapes. Fungal Ecol 28: 76-85. DOI: 10.1016/j.funeco.2016.09.007

Mendenhall CD, Daily GC, Ehrlich PR. 2012. Improving estimates of biodiversity loss. Biol Conserv 151: 32-34. DOI: 10.1016/j.biocon.2012.01.069

Miller OK, Miller H. 1988. Gasteromycetes: Morphological and Development Features with Keys to Orders, Families, and Genera. Mad River Press, California.

Mohanan C. 2014. Macrofungal diversity in the Western Ghats, Kerala, India: members of Russulaceae. J Threat Taxa 6: 5636-5648. DOI 10.11609/JoTT.o3620.5636-48

Mora C, Tittensor DP, Adl S, Simpson AGB, Worm B. 2011. How many species are there on earth and in the ocean?. PLoS Biol 9: e1001127. DOI: 10.1371/journal.pbio.1001127

Morris EK, Caruso T, Buscot F, Fischer M, Hancock C, Maier TS, Meiners T, Müller C, Obermaier E, Prati D, Socher SA, Sonnemann I, Wäschke N, Wubet T, Wurst S, Rillig MC. 2014. Choosing and using diversity indices:insights for ecological applications from the German Biodiversity Exploratories. Ecol Evol 4: 3514-3524. DOI: $10.1002 /$ ece 3.1155

Mycobank. 2020. Basic statistics on MycoBank. MYCOBANK Database. https://www.mycobank.org/page/Stats\%20page

Nakamura A, Kitching RL, Cao M, Creedy TJ, Fayle TM, Freiberg M, Hewitt CN, Itioka T, Koh LP, Ma K, Malhi Y, Mitchell A, Novotny V, Ozanne CMP, Song L, Wang H, Ashton LA. 2017. Forests and their canopies: achievements and horizons in canopy science. Trends Ecol Evol 32: 438-451. DOI: 10.1016/j.tree.2017.02.020

Norros V, Halme P. 2017. Growth sites of polypores from quantitative expert evaluation: Late-stage decayers and saprotrophs fruit closer to ground. Fungal Ecol 28: 53-65. DOI: 10.1016/j.funeco.2017.04.004

Nur 'Aqilah MB, Nurjannah S, Salleh S, Thi BK, Fitri ZA, Faizi MMK, Maideen KMH, Nizam MS. 2020. Elevation influence the macrofung diversity and composition of Gunung Korbu, Perak, Malaysia. Biodiversitas 21: 1707-1713. DOI: 10.13057/biodiv/d210453

O'Hanlon R, Harrington TJ. 2012. Macrofungal diversity and ecology in four Irish forest types. Fungal Ecol 5: 499-508. DOI: 10.1016/j.funeco.2011.12.008

O'Hanlon R, Harrington TJ, Berch SM, Outerbridge RA. 2013. Comparisons of macrofungi in plantations of Sitka spruce (Picea sitchensis) in its native range (British Columbia, Canada) versus nonnative range (Ireland and Britain) show similar richness but different species composition. Can J For Res 43: 450-458. DOI: 10.1139/cjfr2012-0391

Olson DM, Dinerstein E, Wikramanayake ED, Burgess ND, Powell GVN, Underwood EC, d'Amico JA, Itoua I, Strand HE, Morrison JC, Loucks CJ, Allnutt TF, Ricketts TH, Kura Y, Lamoreux JF, Wettengel WW, Hedao P, Kassem KR. 2001. Terrestrial ecoregions of the world: a new map of life on earth. BioScience 51: 933-938. DOI: 10.1641/0006-3568(2001)051[0933:TEOTWA]2.0.CO;2

Ostry ME, Anderson NA, O'Brien JG. 2011. Field Guide to Common Macrofungi in Eastern Forests and Their Ecosystem Functions. United States Department of Agriculture, Pennsylvania. DOI: 10.2737/NRS-GTR-79

Ottosson E, Nordén J, Dahlberg A, Edman M, Jönsson M, Larsson K, Olsson J, Penttilä R, Stenlid J, Ovaskainen O. 2014. Species associations during the succession of wood-inhabiting fungal communities. Fungal Ecol 11: 17-28. DOI: 10.1016/j.funeco.2014.03.003

Parfitt D, Ainsworth AM, Simpson D, Rogers HJ, Boddy L. 2007. Molecular and morphological discrimination of stipitate hydnoids in the genera Hydnellum and Phellodon. Mycol Res 111: 761-777. DOI: 10.1016/j.mycres.2007.05.003

Pegler DN, Roberts RJ, Spooner BM. 1997. British Chanterelles and Tooth Fungi. Royal Botanic Gardens Kew, London.

Petersen JH. 2013. The Kingdom of Fungi. Princeton University Press, New Jersey. DOI: 10.1515/9781400846870

Pickles BJ, Egger KN, Massicotte HB, Green DS. 2012. Ectomycorrhizas and climate change. Fungal Ecol 5: 73-84. DOI: 10.1016/j.funeco.2011.08.009

Piepenbring M, Hofmann TA, Miranda E, Cáceres O, Unterseher M. 2015. Leaf shedding and weather in tropical dry-seasonal forest shape the phenology of fungi - Lessons from two years of monthly surveys in southwestern Panama. Fungal Ecol 18: 83-92. DOI: 10.1016/j.funeco.2015.08.004

Piętka S, Sotnik A, Damszel M, Sierota Z. 2019. Coarse woody debris and wood-colonizing fungi differences between a reserve stand and a managed forest in the Taborz region of Poland. J For Res 30: 10811091. DOI: $10.1007 / \mathrm{s} 11676-018-0612-y$

Pradhan P, Dutta AK, Roy A, Basu SK, Acharya K. 2013. Macrofungal diversity and habitat specificity: a case study. Biodiversity 14: 147161. DOI: $10.1080 / 14888386.2013 .805660$

Pradhan P, Dutta AK, Acharya K. 2015. A low cost long term preservation of macromycetes for fungarium. Protoc Exch. DOI: 10.1038/protex.2015.026

Rajala T, Peltoniemi M, Pennanen T, Mäkipää R. 2012. Fungal community dynamics in relation to substrate quality of decaying Norway spruce (Picea abies [L.] Karst.) logs in boreal forests. FEMS Microbiol Ecol 81: 494-505. DOI: 10.1111/j.1574-6941.2012.01376.x

Rinkes ZL, Weintraub MN, DeForest JL, Moorhead DL. 2011. Microbial substrate preference and community dynamics during decomposition of Acer saccharum. Fungal Ecol 4: 396-407. DOI: 10.1016/j.funeco.2011.01.004

Runnel K, Lõhmus A. 2017. Deadwood-rich managed forests provide insights into the old-forest association of wood-inhabiting fungi. Fungal Ecol 27: 155-167. DOI: 10.1016/j.funeco.2016.09.006

Runnel K, Miettinen O, Lõhmus A. 2021. Polypore fungi as a flagship group to indicate changes in biodiversity - a test case from Estonia. IMA Fungus 12: 2. DOI: 10.1186/s43008-020-00050-y

Santi LP, Kalbuadi DN, Goenadi DH. 2019. Empty fruit bunches as potential source for biosilica fertilizer for oil palm. J Trop Biodivers Biotechnol 4: 90-96. DOI: 10.22146/jtbb.38749

Santos-Silva C, Gonçalves A, Louro R. 2011. Canopy cover influence on macrofungal richness and sporocarp production in Montado ecosystems. Agroforest Syst 82: 149-159. DOI: 10.1007/s10457-0119374-7

Schigel DS. 2012. Fungivory and host associations of Coleoptera: a bibliography and review of research approaches. Mycol Int J Fungal Biol 3: 258-272. DOI: 10.1080/21501203.2012.741078

Schilling JS, Kaffenberger JT, Liew FJ, Song Z. 2015. Signature wood modifications reveal decomposer community history. PLoS One 10: e0126877. DOI: 10.1371/journal.pone.0120679

Schön ME, Nieselt K, Garnica S. 2018. Belowground fungal community diversity and composition associated with Norway spruce along an altitudinal gradient. PLoS One 13: e0208493. DOI: 10.1371/journal.pone.0208493

Seephueak P, Preecha C, Seepheak W. 2017. Diversity of macrofungi in oil palm (Elaeis guineensis Jacq.) plantation in Southern Thailand. Walailak J Sci Technol 15: 201-211. DOI: 10.48048/wjst.2018.2643

Shade A, Peter H, Allison SD, Baho DL, Berga M, Bürgmann H, Huber DH, Langenheder S, Lennon JT, Martiny JBH, Matulich KL, Schmidt TM, Handelsman J. 2012. Fundamentals of microbial community resistance and resilience. Front Microbiol 3: 417. DOI: 10.3389/fmicb.2012.00417

Shay JE, Desjardin DE, Perry BA, Grace CL, Newman DS. 2017. Biodiversity and phylogeny of Marasmius (Agaricales, Basidiomycota) from Madagascar. Phytotaxa 292: 101-149. DOI: 10.11646/phytotaxa.292.2.1

Shuhada SH, Salim S, Nobilly F, Zubaid A, Azhar B. 2017. Logged peat swamp forest supports greater macrofungal biodiversity than largescale oil palm plantations and smallholdings. Ecol Evol 7: 7187-7200. DOI: $10.1002 /$ ece 3.3273

Singer R. 1986. The Agaricales in Modern Taxonomy, 4th edition. Koeltz Scientific, Koenigstein.

Smith ME, Bonito GM. 2012. Systematics and Ecology of Edible Ectomycorrhizal Mushrooms. In: Zambonelli A, Bonito GM (eds) Edible Ectomycorrhizal Mushrooms. Soil Biology, Springer, Heidelberg. DOI: 10.1007/978-3-642-33823-6_2

Spooner B. 2000. The larger cup fungi in Britain: part 1. Field Mycol 1: 137-139. DOI: 10.1016/S1468-1641(10)60072-2

Tadiosa ER, Briones RU. 2013. Fungi of Taal volcano protected landscape, Southern Luzon, Philippines. Asian J Biodivers 4: 46-64. DOI: 10.7828 /ajob.v4i1.296

Thomas WS. 1928. Field Book of Common Gilled Mushrooms. G. P. Putnam's Sons, New York.

Tóthmérész B. 1995. Comparison of different methods for diversity ordering. J Veg Sci 6: 283-290. DOI: 10.2307/3236223

Tsujino R, Yumoto T, Kitamura S, Djamaluddin I, Darnaedi D. 2016. History of forest loss and degradation in Indonesia. Land Use Policy 57: 335-347. DOI: 10.1016/j.landusepol.2016.05.034

Tuheteru FD, Husna, Albasri, Arif A, Wulan SA, Kramadibrata K. 2019. Arbuscular mycorrhizal fungi associated with adaptive plants in gold 
mine tailing. Biodiversitas 20: 3398-3404. DOI: 10.13057/biodiv/d201137

Turubanova S, Potapov PV, Tyukavina A, Hansen MC. 2018. Ongoing primary forest loss in Brazil, Democratic Republic of the Congo, and Indonesia. Environ Res Lett 13: 074028. DOI: 10.1088/1748 9326/aacd1c

Vulinović JN, Lolić SB, Vujčić SB, Matavulj MN. 2018. Schizophyllum commune - the dominant cause of trees decay in alleys and parks in the City of Novi Sad (Serbia). Biol Serb 40: 26-33. DOI: 10.5281/zenodo.2452495

Wei J, Yang Y, Hobbie EA, Yan W. Ectomycorrhizal fungal resources of Inner Mongolia Autonomous Region: above ground macrofungi and belowground ectomycorrhizae. New For (Dordr) 50: 521-537. DOI: 10.1007/s1 1056-018-9691-Z

Wu F, Chen JJ, Ji XH, Vlasak J, Dai YC. 2017. Phylogeny and diversity of the similar polypore genera Rigidoporus, Physisporinus, Oxyporus, and Leucophellinus. Mycologia 109 (7): 49-765. DOI: $10.1080 / 00275514.2017 .1405215$
WWF. 2005. 10 Negara dengan Hutan Terbesar. WWF Indonesia. [Indonesian]

Yang G, Roy J, Veresoglou SD, Rillig MC. 2021. Soil biodiversity enhances the persistence of legumes under climate change. New Phytol 229: 2945-2956. DOI: 10.1111/nph.17065

Ye L, Li H, Mortimer PE, Xu J, Gui H, Karunarathna SC, Kumar A, Hyde KD, Shi L. 2019. Substrate Preference Determines Macrofungal Biogeography in the Greater Mekong Sub-Region. Forests 10: 824. DOI: $10.3390 / \mathrm{f} 10100824$

Yilmaz H, Zencirci N. 2016. Ethnomycology of macrofungi in the Western Black Sea Region of Turkey: Identification to marketing. Econ Bot 70: 270-284. DOI: 10.1007/s12231-016-9353-z

Zotti M, Persiani AM, Ambrosio E, Vizzini A, Venturella G, Donnini D, Angelini P, Di Piazza S, Pavarino M, Lunghini D, Venanzoni R, Polemis E, Granito VM, Maggi O, Gargano ML, Zervakis GI. 2013. Macrofungi as ecosystem resources: Conservation versus exploitation. Plant Biosyst 147: 219-225. DOI: $10.1080 / 11263504.2012 .753133$ 